研究

\title{
温間成形における鉄系粉末の圧密化挙動に及ぼす潤滑剤の影響
}

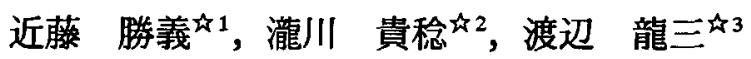 \\ 41 東京大学先端科学技術研究センター, ₹ 153-8904 目黒区駒場 4-6-1. \\ 42 住友電気工業侏伊丹研究所, 宁 664-0016 伊丹市昆陽北 1-1-1. \\ 中 3 東北大学大学院工学研究科, 干980-8579 仙台市青葉区荒巻字青葉 02.
}

\section{Effect of Lubricant on Warm Compaction Behavior of Iron Powder Particles}

\author{
Katsuyoshi Kondoh ${ }^{\text {4 } 1}$, Takatoshi Takikawa ${ }^{\text {t2 }}$ and Ryuzo Watanabe \\ ${ }^{\star 1}$ Research Center for Advanced Science and Technology, University of Tokyo, 4-6-1 Komaba Meguro-ku, Tokyo $153-8904$. \\ \& Itami R\&D Sumitomo Electric Industries Ltd., 1-1-1 Koya-kita, Itami 664-0016. \\ ${ }_{\star 2}^{3}$ Dept. Materials Processing, Graduate School of Eng., Tohoku University, Aoba-ku Sendai 980-8579.
}

Received April 24, 2000

\section{SYNOPSIS}

The effect of the lubricant on the compaction behavior in warm compaction of iron powder was examined by using Cooper-Eaton equation. Particle rearrangement depends on the lubrication effect between powder particles and is more dominant on its compaction behavior than the plastic deformation of powder particles until $423 \mathrm{~K}$. The total fractional volume compaction calculated by this method corresponds to the measured density of the green compact. Therefore, this analytical method is available to evaluate the warm compaction behavior quantitatively.

KEYWORDS

Warm compaction, Cooper-Eaton equation, Lubricant, Melting point, Particle rearrangement

\section{1 緒 言}

鉄系焼結材の自動車用部品への展開を図るべく,これまで に赎結体の高強度化を目指した新しい原料粉末やプロセスの 検討か進められてきた. その結果，焼結体密度の向上を目的 として例えば， $\alpha$ 相焼結用粉末 ${ }^{1} や 2$ press-2sinter 法, 焼結鈠造

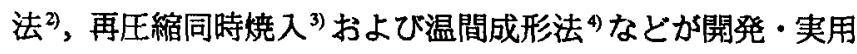
化されている. なかでも，高密度成形体の創製によって焼結 体の高密度化を達成することを特徵とする温間成形法は他の 製法に比へて焼結工程以降での密度変化が小さいことから焼 結体の寸法精度の向上も期待されている.ゆえに温間成形法 における粉末粒子の圧密化挙動を把握することは成形体の高 密度化を議論する上において重要な課題である。これまでに 尾崎らクによって耐熱性離型潤滑郕を添加した鉄系原料粉末
について温間成形過程での圧密化挙動の解析が行なわれ，潤 滑剂の特性と粒子の偏析防止との関係が检討されている.し かしながら，温間成形法における粒子の圧密化挙動に及ぼす 離型潤滑㓮の影響に関する詳細な検討結果付報告されていな い.そこで，このような観点から本報では融点の異なる離型 潤滑凨を添加した鉄系粉末の温間成形過程における粉末粒子 の圧密化挙動の温度依存性について検討する。

\section{2 実験方法}

2.1 供試粉末の特性

出発原料として侏神戸製鋼所製低合金鉄系粉末アトメル 46F4H (Fe-0.5Ni-1.0Momass\%) を準備し，Table 1に示す特性を 有する 3 種類の離型潤滑剤から 1つを選定して上記の原料粉

Table 1 Characteristics of lubricant powder used in this study.

Melting point (K) Aqua (\%) Acid (mgKOH/g) Metallic (\%)

\begin{tabular}{lllll}
\hline Lub I & 352 & 0.1 & 2.3 & 0.8 \\
Lub II & 393 & 0.1 & 2.8 & 0.9 \\
LubIII & 431 & 0.1 & 2.9 & 1.2
\end{tabular}


末に $0.8 \mathrm{out} \%$ 添加した混合粉末を試料とした. 使用した離型 潤滑剤はいずれも金属基ステアリン酸粉末であるが，金属分 の含有量を変えることで融点を約 $350 \mathrm{~K} \sim 430 \mathrm{~K}$ とした. なお， ここでは粒子の圧密化挙動解析を主目的とすることから原料 粉末中において凝集・偏析の可能性がある黒鉛粉末は添加せ ず実験を行なった.一方，後述するように粉末粒子の圧密 化挙動解析においては粒子の塑性变形能を把握する必要があ るが, 例えば圧縮試験によって粒子 1 個の圧縮耐力を正確に 測定することは困難である。このような課題に対してこれま でに著者らのは粉末を真密度レベルまで固化した索材の圧縮 耐力が圧密化機構における粒子の塑性変形能と強い相関があ ることを確認している.そこで，本研究においても同様に出 発原料粉末に対して焼結工程と熱間鉎造工程を施すことで相 対密度 99\%以上のバルク体を作製し，その素材の圧縮耐力を 粒子の塑性変形抵抗を表す指標として用いた。具体的には, 先ず上記の鉄系粉末を金型内に充填して成形面圧 882MPa で 圧粉し，得られた成形体を $1423 \mathrm{~K}$ に管理した水素・窒素の混 成ガス雾囲気中で $3.6 \mathrm{ks}$ 加熱保持して焼結体を作製する.これ を高周波加熱装置によって1273Kに加熱し，その温度で60s間 保持した後に閉塞金型熱間鐉造法によって面圧 $882 \mathrm{MPa}$ を付 与して焼結鍛造素材を作製する.さらにこの素材を上記と同 一条件下で焼結および熱間鍛造工程を繰り返すことで相対密 度 99\%以上のバルク体とした. 得られた焼結鍛造体から5 $\times 5$ $\times 10 \mathrm{~mm}$ の直方体試料を採取し， $250 \mathrm{kN}$ 万能式圧縮試験機を用 いて常温から 473Kまでの温度域における住縮耐力を測定し た.

\section{2 粉末压縮試験方法}

温間成形過程における粉末粒子の圧密化挙動を評価すべく， 本実験では $250 \mathrm{kN}$ 万能式圧縮試験機に金型加熱用恒温槽を取 り付け，試料粉末 $7 \mathrm{~g}$ を充填した成形用金型 (内径; $\phi 11.3 \mathrm{~mm}$, 型材質; 超硬)を恒温槽内にセットした. 試料粉末内に㨉入し た熱電対の温度が所定の温度に到達後, その温度で 600 s 保持 した後に圧縮試験を行なった。ここでは試験温度を $296 \mathrm{~K}$, $323 \mathrm{~K}, 373 \mathrm{~K}, 423 \mathrm{~K}$ の 4 水準とし, 圧縮時の上パンチの下降速 度を $0.5 \mathrm{~mm} / \mathrm{s}$ 一定とした. 粉末の王縮試験において先ず, 粉 末に作用する荷重と上パンチの変位量との関係を測定してそ の圧縮変位量から成形体体積の減少量を算出した.そして金 型から抜出した成形体の全長および直径から成形体の体積を 求め,この值が金型内での最大加圧下での粉末体積と同一で あると仮定して，先に測定した成形体体積の隇少量を加算す ることで各成形圧力と成形体体積との相関(圧力 $\mathrm{P}$ 一体積 $\mathrm{V}$ 曲 線)を求めた. 粒子再配列機構の影㸷を厳密に評価するために は, 可能な限り低圧力条件での圧縮変位量を測定することが 有効であることから本実験では最小荷重を $98 \mathrm{~N}$ とし，最大荷 重 $78.4 \mathrm{kN}$ (最大成形圧力 $784 \mathrm{MPa}$ ) に設定した。 なお，離型郕 の潤滑効果を調查するために金型から圧粉成形体を抜き出す 際の荷重も併せて測定した.

2.3 Cooper-Eaton 式による粉末の圧密化挙動解析方法 本研究では異なる粒子径を有する粉末の圧縮举動を解析す
るにあたり、これまでと同様に (1)式に示す Cooper-Eaton 式》 を用いた. V(0)は無加圧状態での粉末の充填体積であり，本 実験では各粉末の見掛け密度から求めた. $\mathrm{V}(\infty)$ は空隙か存在 しない状態での粉末体積であり，秤量した試料粉末の質量と 真密度を用いて算出した.

$$
\mathrm{V}=\frac{\mathrm{V}(0)-\mathrm{V}(\mathrm{p})}{\mathrm{V}(0)-\mathrm{V}(\infty)}-\mathrm{a} 1 \exp (-\mathrm{k} 1 / \mathrm{P})+\mathrm{a} 2 \exp (-\mathrm{k} 2 / \mathrm{P})
$$

$\mathrm{a} 1, \mathrm{k} 1$; Coefficient of particle rearrangement a2, k2; Coefficient of plastic deformation of powder particle $(\mathrm{a} 1+\mathrm{a} 2=1)$

本研究では粉末粒子を金型内で圧縮成形する際の圧密化機 構を粒子の再配列による体積堿少と粒子の塑性変形(或いは破 碎)による体積隇少からなると仮定し，確率過程論に基づいて (1)式のような2項の指数関数の線形式として全体積圧縮率を 記述した.よって，第 1 項は金型内へ粉末を充填した際に生 じた空隙の閉鎖によって粒子が再配列する圧縮初期段階での 綒密化現象 (粒子再配列機構)であり，第 2 項は比較的高圧力 が付与された際の粉末粒子の塑性変形或いは破碎の進行によ る絰密化現象 (塑性変形機構) とした.

ここで, a 值は極限圧力付加状態 $(\mathrm{P} \rightarrow \infty)$ での全体積圧縮量 に占めるそれそれの圧密化機構の奇与度を意味しており，a1 と a2 はそれそれ粒子再配列機構と塑性変形機構に対応する. また本計算プログラムでは $\mathrm{a}$ 值の総和 $(\mathrm{a} 1+\mathrm{a} 2)$ は常に 1 となる ように考虑しており, 值が大きい機構ほど粉末の圧密化挙動 を支配しているといえる.一方, $\mathrm{k}$ 值は各圧密化機構の開始相 当圧力を表しており，この值が小さいほど比較的低い圧力条 件下で粉末の絰密化が進行することを意味する．また本実験 では，圧縮試験により得られた圧力 $\mathrm{P}$ 一体積 $\mathrm{V}$ の相関テータ から非線形最小2乗法によって算出したa值およびk值を用い て各圧密化機構による体積圧縮率の総和 $\mathrm{V}(0 \leqq \mathrm{~V} \leqq 1)$ を算出 する.その結果，粉末の圧縮特性の成形圧力依存性および絾 密化過程での到達圧密率を定量的に把握できる.

\section{3 結果および考察}

3.1 圧縮変位量々離型時の抜き荷重の温度依存性

金型内に充填した試料粉末に対して735MPa の成形圧力を 付与した際の圧縮変位量と粉末温度の関係を Fig.1に示す.粉 末温度の增加と共に圧縮変位量憎加する傾向にあるが,Lub I或いはIIを含む試料では粉末温度がある範囲を越えると変位 量は逆に低下しており，圧密化が阻止されることがわかる. また Fig.2に示すように離型時の拔き荷重(成形体と金型壁面 との摩擦力に相当)の温度依存性も润滑剤によって異なり， Lub I或いはIIを含む試料では急激に抜き荷重が增加する温度 域が存在する.このように抜き荷重が急增した圧粉成形体の 表面には圧縮方向に幾つかの縦筋と局所的にむしれた領域か 認められ，金型壁面と㠜着した表面性状を呈していた.なお， Lub I を添加した試料では粉末温度か3 373Kの条件下において 約10kNの高い抜き荷重を発生し,成形体表面全体において金 
型との焼付き現象が生じたために423Kでの圧緥試験は実施し なかった.

3.2 温間成形における粉末の圧密化への粒子再配列および塑性 変形の寄与

粉末粒子の圧縮機構における粒子再配列の寄与度を表すa1 值の粉末温度依存性を Fig.3に示す. Fig.1に示した压縮変位 量の結果と類似しており, 全体として $\mathrm{a} 1$ 值は粉末温度の上昇 に伴なって增加する傾向にあるが, 粉末温度がLub Iでは 323Kを，Lub IIでは 373Kをそれそれ越えるといずれも a1 值 は大きく低下しており，常温でのa1值を下回る值となっている.

この結果を用いて粒子再配列による体積圧縮率V1の成形圧 力依存性を計算した結果を Fig.4に，また成形圧力 784MPa を 付与した場合のV1值の温度依存性を Fig.5に示す. いずれの

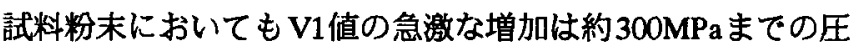
力領域で認められ，それ以降では㩆著な增加はないことから
13.2
13.0
12.8
12.6
12.4
12.2
12.0
12.8
12.6
12.4
12.2
12.0
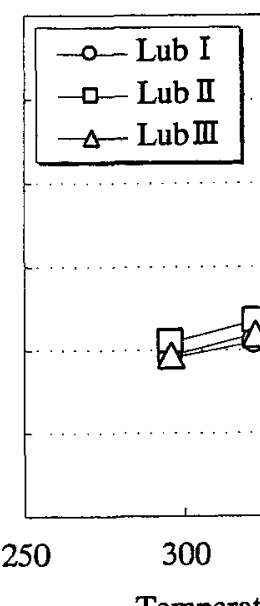

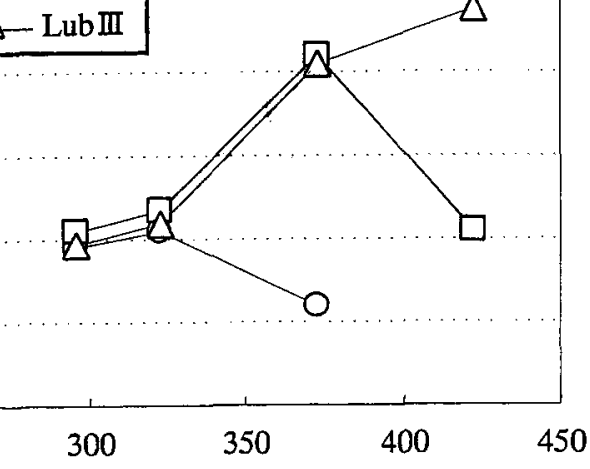

Temperature of powder particle (K)

Fig.1 Dependence of traveling displacement at compacting pressure of $735 \mathrm{MPa}$ on temperature of powder particle in warm compaction die.

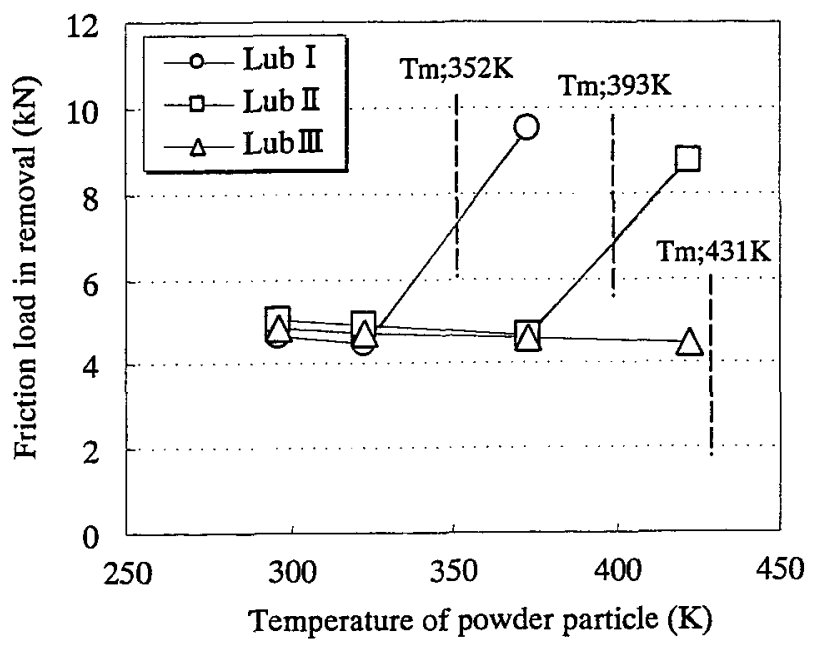

Fig.2 Changes of friction load between green compact and die wall in removal.
この圧力範囲内で粒子再配列による粉末の緻密化機構はほほ 完了すると考えられる.Fig.5に示すように 784MPa 程度の高 成形圧力を付与した場合, Lub I を含む試料粉末では粉末温度 が 323K の場合に V1 值は最大となり，粉末温度が 373Kにな るとかえってその值は低下している.Lub IIを含む試料におい ても同様に，粉末温度が373Kで V1 值は最大值を有してそれ 以上の温度では滅少する。しかしながら，Lub III を含む試料 粉末ではV1值にこのような変化はなく, 粉末温度の上昇と共 にV1值も増加しており，温間成形における粒子再配列による 圧密化が温度上昇と共に進行していると考えられる．前記の 離型潤滑剤の特性および離型時の抜き荷重の変化などを踏ま えると，このような結果は温間成形過程における離型凨の潤 滑効果に関係していると考えられる．Fig.2に示したように Lub I或いはLub II を含む試料粉末ではいずれも粉末温度がそ れそれの離型潤滑剤の融点 $(\mathrm{Tm})$ を越えると, 離型後の成形体 表面に金型との凝着部が見られたが，これは離型润滑凨が液 化するために粉末粒子と金型壁面の間に良好な潤滑皮膜が成 形され難くなり，その結果，圧縮時およひ離型時に成形体表 面と壁面間で焼付現象を生したことによると考えられる。粉 末粒子間においても同様の理由により安定な潤滑膜が形成さ れないために粒子同士の金属接触が生じて局所的な凝着現象 を誘発し，そのために圧縮過程において粒子の再配列機構が 阻害されたと考えられる。

次に, 成形圧力 784MPa を付与した際の塑性変形機構によ る体積圧縮率 V2の温度依存性を Fig.6に示す. Fig.5に示した 粒子再配列による体積圧縮率V1の結果に比へて粉末温度の増 加に対する V2 值の変化は小さく顕著な依存傾向は見られな い.これはFig.7に示す熱間鍛造体の高温圧縮耐力の結果から わかるように,473K程度までの温度領域では圧縮耐力に大き な変化がないことから粉末の塑性変形能も顕著に低下してい ないといえる。ゅえに，同温度域においては粉末温度の上昇

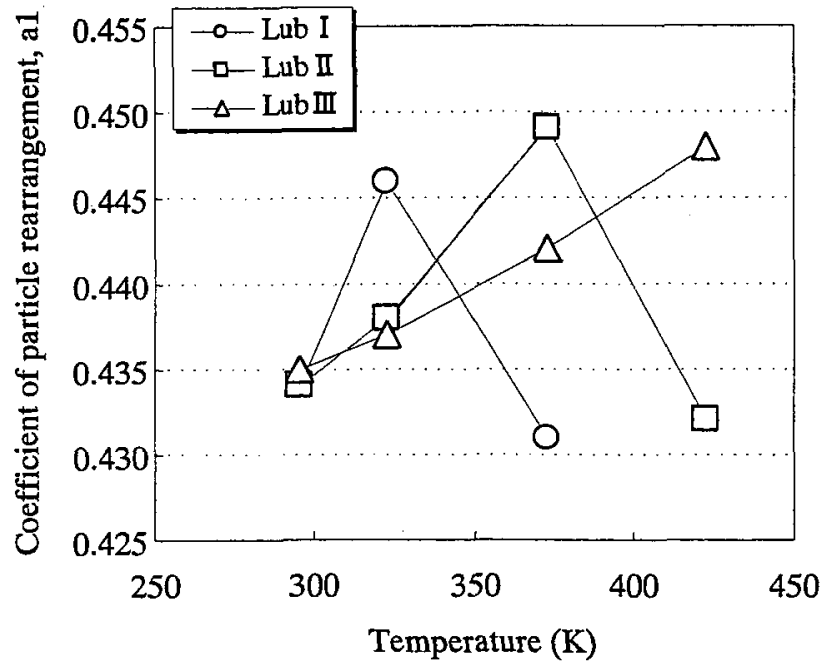

Fig.3 Dependence of coefficient of rearrangement of powder particle on temperature of powder particle in warm compaction die. 
に対して粒子の塑性変形による圧密化過程が著しく変化する ことはなく，その結果，V1值と比較して粉末温度の增加に対

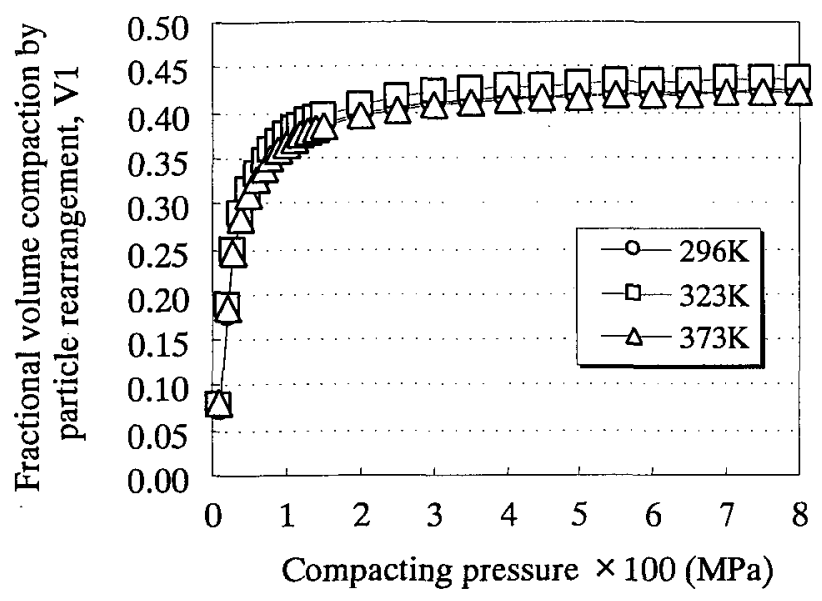

(a)

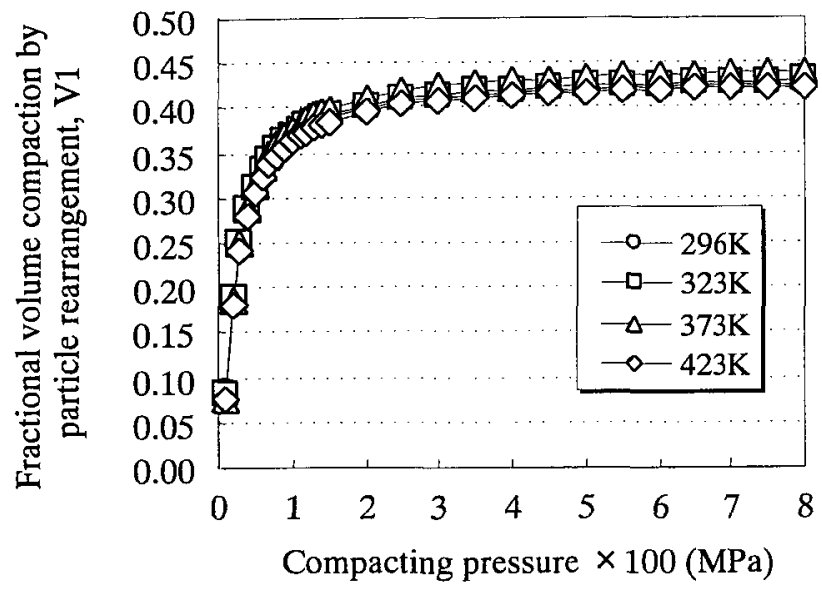

(b)

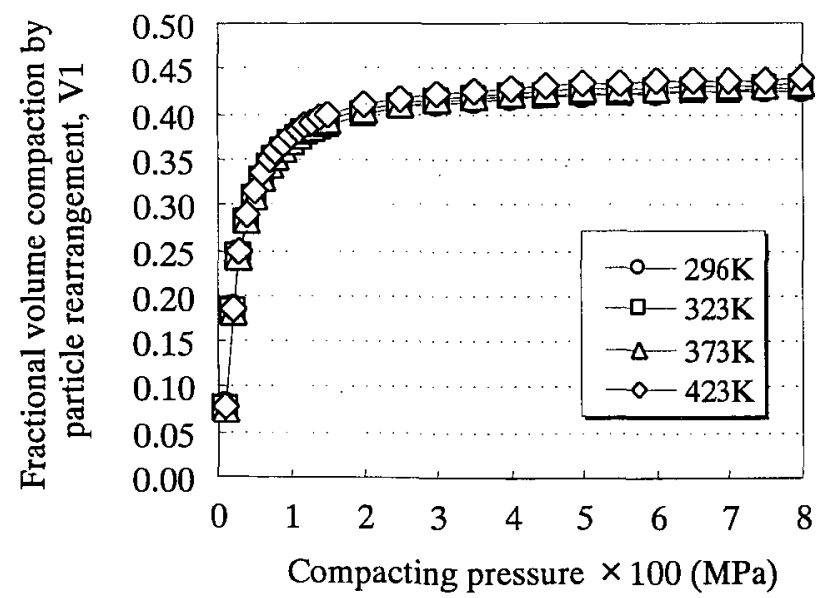

(c)

Fig.4 Calculation results for frictional volume compaction by rearrangement of powder particle in warm compaction of pre-alloy iron powder. (a) Lubricant I, (b) Lubricant II, (c) Lubricant III
するV2 值の変化が小さくなったと考えられる. 3.3 全体積圧縮率と成形体密度との関係

上記のV1值およびV2值を用いて温間成形過程における粉 末の全体積圧縮率 V と粉末温度の関係を求めた，その結果を Fig.8に示す. Lub I或いはLub II 含む試料粉末においては粉 末温度の増加に対してそれそれれの離型潤滑剤の融点を越える とV值は減少しており，Fig.5に示した粒子再配列による体積 圧縮率の結果と同じ傾向にある．このことから温間成形過程 における粉末の全圧縮体積率は粒子再配列機構に大きく依存 しているといえる。また 784MPa の成形圧力を付与した際の 圧粉体の実測密度と全体積圧縮率との関係を Fig.9に示す.こ れに見るように2つのテータを除くとV值は密度に対してほ ほ同一直線上にプロットされ，求めた計算結果は実測值とよ い対応を有している.このことから本手法によれば温間成形

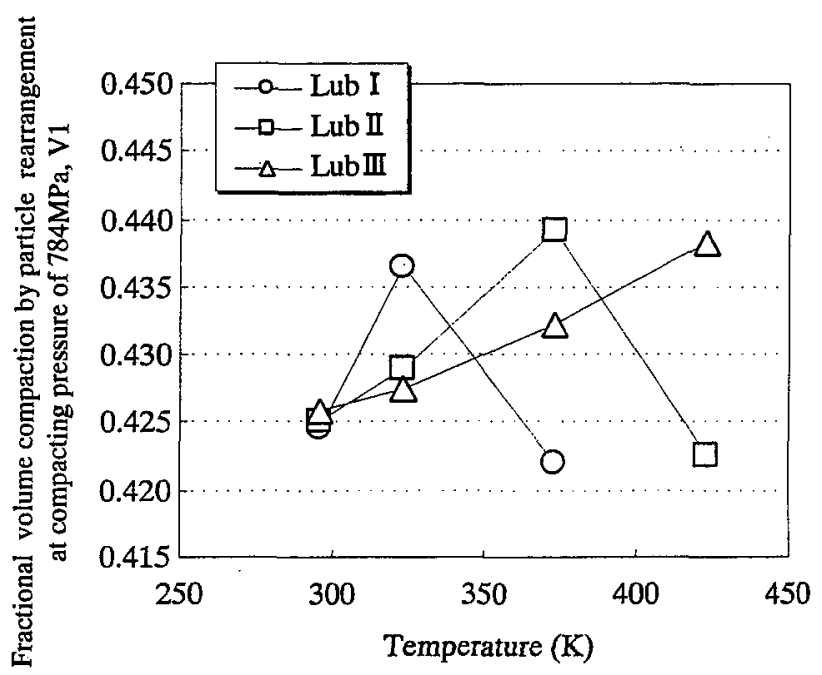

Fig.5 Effect of lubricant powder on fractional volume compaction by rearrangement of powder particle at warm compaction pressure of $784 \mathrm{MPa}$.

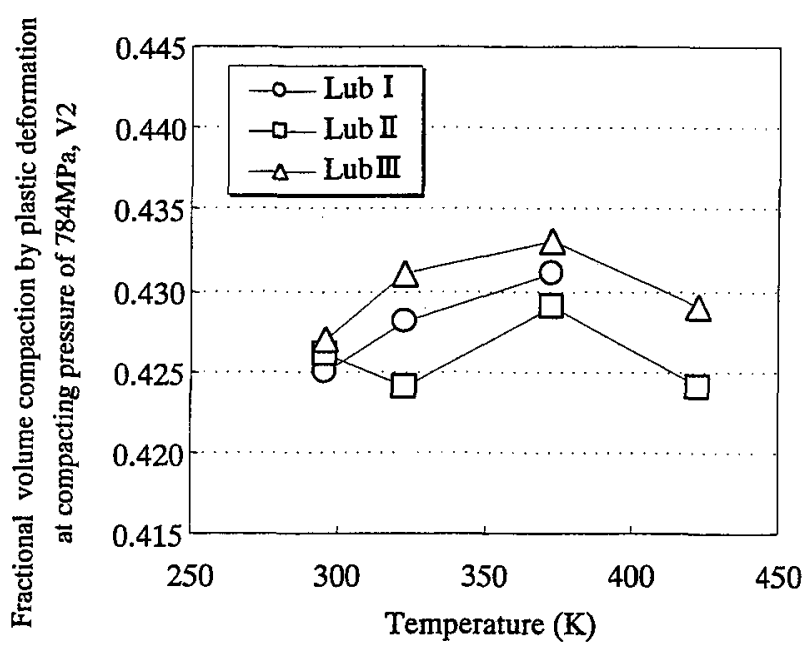

Fig.6 Effect of lubricant powder on fractional volume compaction by plastic deformation of powder particle at warm compaction pressure of $784 \mathrm{MPa}$. 


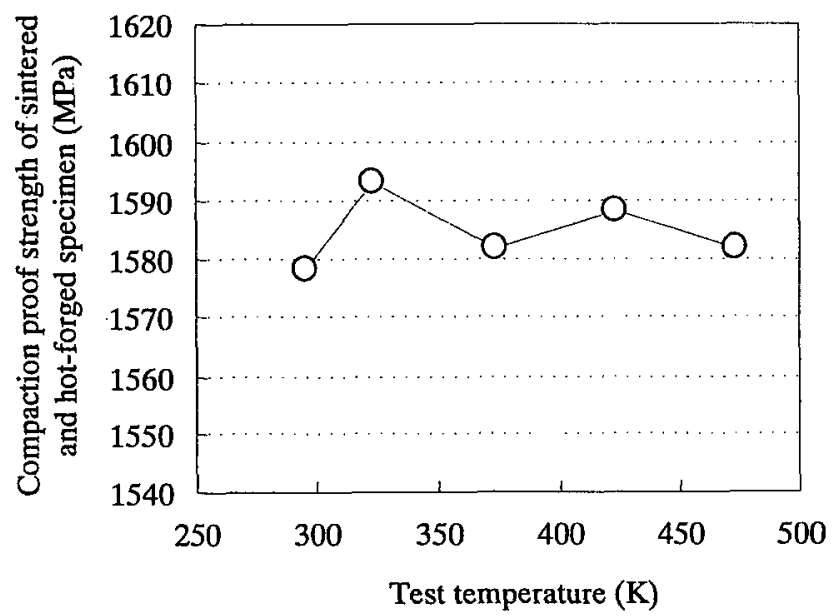

Fig.7 Change of compaction proof strength of sintered and hotforged specimen at elevated temperature.

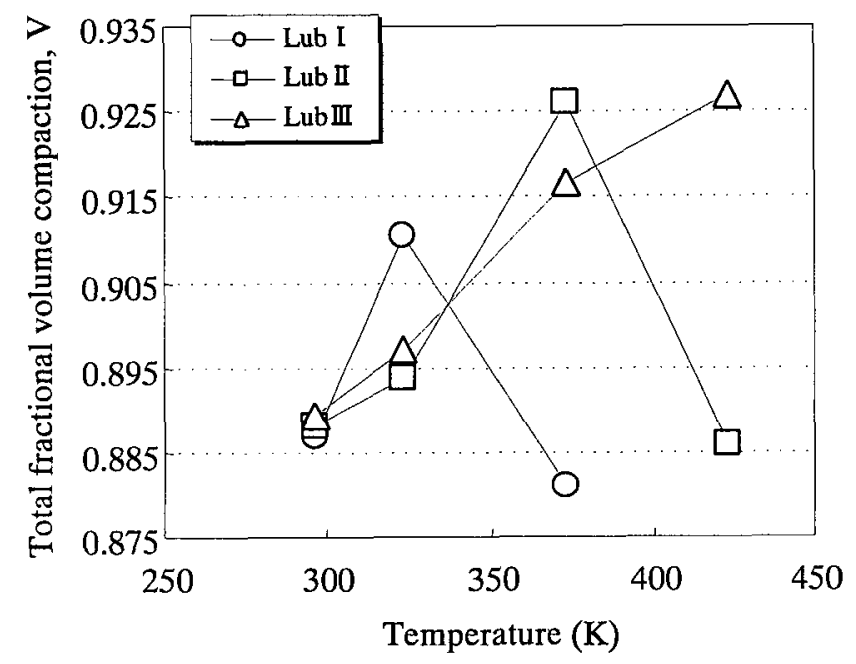

Fig.8 Dependence of total frictional volume compaction on temperature of powder particle in warm compaction die.

過程における粉末の圧密化挙動について定量的な解析・評価

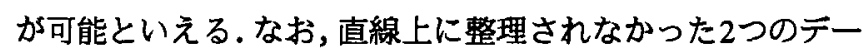
夕に関しては，いずれも潤滑㶡の融点以上の温度域で圧縮し た試料であり，上述したように粒子と金型壁面間での凝着現 象を伴っている. 本来ならば，粉末の圧密化挙動解析におい てこのような摩擦現象も検討する必要があるが，本手法では この影響は考虑されていない.このことが実測值とよい相関 を示さなかった原因の一つと考えられるが,この点に関して は今後さらに詳細な解析が必要である.

\section{4 結 論}

低合金鉄系粉末の温間成形過程における粉末粒子の圧密化

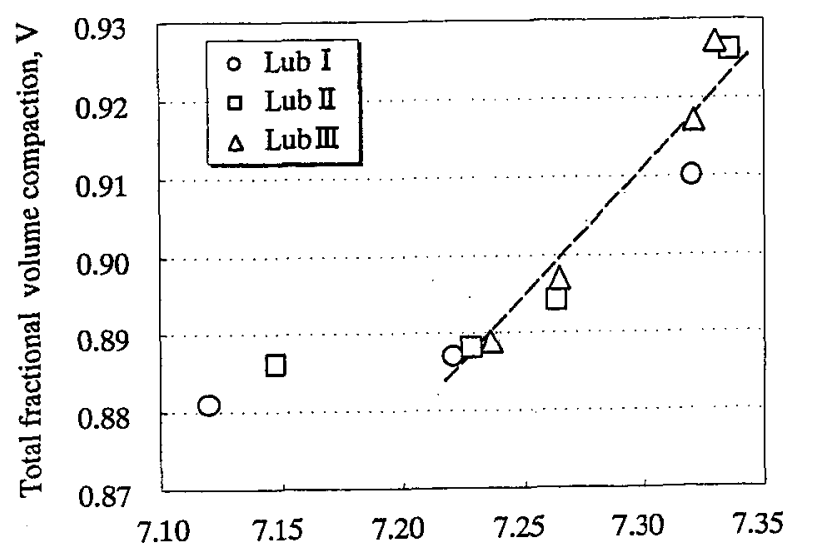

Green density at compacting pressure of $784 \mathrm{MPa}\left(\mathrm{Mg} / \mathrm{m}^{3}\right)$

Fig.9 Relationship between total fractional volume compaction and green density at warm compaction pressure of $784 \mathrm{MPa}$.

挙動に及ぼす離型潤滑剤の影響について Cooper-Eaton 実験式 を用いて検討した. 本研究で得られた結果を以下に示す.

(1) 温間成形過程における粉末の粒子再配列機構は粉末中に含 まれる離型剤の潤滑効果に依存しており，離型㓮の融点以 上では粒子間に安定な閵滑膜が形成され難くなるために粒 子再配列は阻害される.

(2) $423 \mathrm{~K}$ 付近までの温度域での温間成形過程では粉末の圧密 化に対する粒子の塑性変形機構の寄与度は小さく,粒子再 配列機構が支配的である.

(3) 本解析手法により求めた全体積圧縮率は成形体密度の実測 值とよい対応を有しており,温間成形法における粉末の圧 密化挙動を定量的に評価できる.

\section{文献}

1) Metal Powder Report, July/August, (1995)33.

2) Metal Powder Report, June, (1995)7.

3) 瀧川ら: "再圧縮同時焼入した Fe-Mo-Cu-C系佬結鋼部品", 粉体および粉末治金, 46(1999)544-547.

4) 石原: "コネクティングロッドの高強度化一焼結鍛造・熱 間鍛造の住み分けー ", 粉体および粉末治金, 46(1999)505509.

5) 尾崎ら : " 而熱性润滑剤を添加した偏析防止粉の温間での 圧密化機構と焼結体特性 ", 平成 11 年度春季粉体粉末冶金 協会講演概要, (1999)92.

6) 近藤ら : "急冷凝固アルミニウム合金粉末の圧密化挙動に 及ほす粒子径の影響", 粉体および粉末治金, 47(2000)853859.

7) A.R.Cooper and L.E.Eaton: "Compaction Behavior of Several Ceramics Powders", J. Amer. Ceram. Soc., 45(1962)97-101. 